Marquette University

e-Publications@Marquette

7-1998

Proton NMR Spectroscopy as a Probe of Dinuclear Copper(II)

Active Sites in Metalloproteins. Characterization of the Hyperactive Copper(II)-Substituted Aminopeptidase from

\title{
Aeromonas proteolytica
}

Richard C. Holz

Marquette University, richard.holz@marquette.edu

Brian Bennett

Marquette University, brian.bennett@marquette.edu

Guanjing Chen

Utah State University

Li-June Ming

University of South Florida

Follow this and additional works at: https://epublications.marquette.edu/physics_fac

Part of the Physics Commons

\section{Recommended Citation}

Holz, Richard C.; Bennett, Brian; Chen, Guanjing; and Ming, Li-June, "Proton NMR Spectroscopy as a Probe of Dinuclear Copper(II) Active Sites in Metalloproteins. Characterization of the Hyperactive Copper(II)Substituted Aminopeptidase from Aeromonas proteolytica" (1998). Physics Faculty Research and Publications. 55.

https://epublications.marquette.edu/physics_fac/55 


\title{
Proton NMR Spectroscopy as a Probe of Dinuclear Copper(II) Active Sites in Metalloproteins. Characterization of the Hyperactive Copper(II)-Substituted Aminopeptidase from Aeromonas proteolytica
}

\author{
Richard C. Holz \\ Department of Chemistry and Biochemistry, \\ Utah State University, \\ Logan, UT \\ Brian Bennett \\ Department of Chemistry and Biochemistry, \\ Utah State University, \\ Logan, UT \\ Guanjing Chen \\ Department of Chemistry and Biochemistry, \\ Utah State University, \\ Logan, UT
}


NOT THE PUBLISHED VERSION; this is the author's final, peer-reviewed manuscript. The published version may be accessed by following the link in the citation at the bottom of the page.

\title{
Li-June Ming \\ Department of Chemistry and Institute for Bimolecular Science, University of South Florida, Tampa, FL
}

\begin{abstract}
Proton NMR spectra of the hyperactive $\mathrm{Cu}(\mathrm{II})$-substituted aminopeptidase from Aeromonas proteolytica (AAP) were recorded in both $\mathrm{H}_{2} \mathrm{O}$ and $\mathrm{D}_{2} \mathrm{O}$ buffered solution at $\mathrm{pH}$ 6.7. Several remarkably sharp, well resolved hyperfine shifted ${ }^{1} \mathrm{H}$ NMR signals were observed in the 70 to $-20 \mathrm{ppm}$ chemical shift range. That hyperfine shifted signals were observed is due to spin-coupling of the two $\mathrm{Cu}(\mathrm{II})$ ions. Comparison of the spectra recorded in $\mathrm{H}_{2} \mathrm{O}$ and $\mathrm{D}_{2} \mathrm{O}$ buffered solutions indicated that the signals at 44.6, 43.3, and $17.7 \mathrm{ppm}$ were solvent exchangeable. The two most strongly downfield shifted signals were assigned to imidazole $\mathrm{N}-\mathrm{H}$ protons of the two coordinated histidine residues, while the remaining exchangeable signal was assigned to a peptidyl $\mathrm{N}-\mathrm{H}$ proton that is in close proximity to the dicopper(II) center. One-dimensional NOE studies at $\mathrm{pH} 6.7$ revealed two $\mathrm{Y}-\mathrm{CH}_{2}-\mathrm{CH}<$ moieties that were assigned to coordinated aspartic acid and histidine residues. In addition, a $\mathrm{Y}-\mathrm{CH}_{2}-\mathrm{CH}_{2}-\mathrm{CH}<$ moiety was also identified and was assigned to the coordinated glutamic acid residue, Glu152. All of the hyperfine shifted signals for $[\mathrm{CuCu}(\mathrm{AAP})]$ sharpened and shifted toward the diamagnetic region as the temperature was increased following Curie behavior. Fits of these data and those of a series of magnetically diverse $\mu$-phenoxo and $\mu$-alkoxo dicopper(II) model complexes to the population distribution of the ground and first excited states, provided information on the magnetic properties of dicopper(II) clusters. These fits indicated that the two $\mathrm{Cu}$ (II) ions in AAP are ferromagnetically coupled with a $2 \mathrm{~J}$ value of $50+40 \mathrm{~cm}^{-1}$. These data provide the first structural information regarding the hyperactive [CuCu(AAP)] enzyme and are discussed in terms of the previously proposed mechanism of action for AAP.
\end{abstract}

\section{Introduction}

Enzymes containing dinuclear copper centers play important roles in nature such as the oxidation of organic molecules coupled to the reduction of dioxygen, reduction of nitrogen oxides, dioxygen transport, and hydrolysis chemistry. . $^{2,3}$ Consequently, the characterization of their structure and function is a problem of

Journal of the American Chemical Society, Vol 120, No. 25 (July 1, 1998): pg. 6329-6335. DOI. This article is (C) American Chemical Society and permission has been granted for this version to appear in e-Publications@Marquette. American Chemical Society does not grant permission for this article to be further copied/distributed or hosted elsewhere without the express permission from American Chemical Society. 
outstanding importance. A fundamental and, as yet, largely unexplored issue is the determination of the structural and magnetic properties of dinuclear copper(II) centers in biological systems using ${ }^{1} \mathrm{H}$ NMR spectroscopy. ${ }^{1} \mathrm{H}$ NMR is a natural technique to probe these systems because only protons proximate to the paramagnetic center are affected. ${ }^{4}$ Recently, it was shown that both antiferromagnetically and ferromagnetically coupled dicopper(II) model complexes provide relatively sharp, hyperfine shifted ${ }^{1} \mathrm{H}$ NMR signals. ${ }^{5-17}$ This is in contrast to mononuclear $\mathrm{Cu}$ (II) centers which exhibit considerable NMR line broadening oftentimes making ${ }^{1} \mathrm{H}$ NMR signals unobservable. ${ }^{18}$ The observation of hyperfine shifted signals for dicopper(II) centers is dependent upon the population distribution between the ground and excited states which is, in turn, related to the magnitude of the exchange constant, $2 J .{ }^{19}$ These model studies showed that hyperfine shifted ${ }^{1} \mathrm{H}$ NMR signals could be easily observed and both one- and two-dimensional ${ }^{1} \mathrm{H}$ NMR techniques could be successfully performed on dicopper(II) complexes.

Of particular interest are di- and trinuclear metallohydrolases that contain carboxylate rich coordination environments. ${ }^{12,20-24}$ Specifically, we are interested in the aminopeptidase from Aeromonas proteolytica (AAP) which catalyzes the hydrolysis of a wide range of $\mathrm{N}$ terminal amino acid residues from proteins and polypeptides. ${ }^{25-27}$ AAP possesses ideal biological properties for studying hydrolase activity catalyzed by dinuclear metal centers. ${ }^{28}$ AAP is a small, monomeric enzyme (32000 Da), that contains two g-atoms of zinc per mol of polypeptide, and is thermostable for several hours at $70{ }^{\circ} \mathrm{C} .{ }^{23,28} \mathrm{AAP}$ has been crystallographically characterized and possesses a $(\mu-$ aqua)( $\mu$-carboxylato)dizinc(II) core with a terminal carboxylate and histidine residue coordinated to each metal ion. ${ }^{29}$ Substitution of the two g-atoms of $\mathrm{Zn}(\mathrm{II})$ with $\mathrm{Co}(\mathrm{II}), \mathrm{Cu}(\mathrm{II})$, or Ni(II) provides enzymes are which hyperactive by $7.7,6.5$, and 25 times, respectively, toward certain substrates. ${ }^{30-32}$ Moreover, the addition of $1 \mathrm{~mol}$ of $\mathrm{Cu}(\mathrm{II})$, $\mathrm{Co}(\mathrm{II})$, or $\mathrm{Ni}$ (II) to apo-AAP followed by the addition of $\mathrm{Zn}$ (II) provides discrete heterodimetallic active sites that are enzymatically hyperactive compared to native AAP. ${ }^{21,22}$ For $\mathrm{Ni}(\mathrm{II})$ and $\mathrm{Cu}(\mathrm{II})$, nearly a 90- and 100-fold increase in activity are observed, respectively. ${ }^{30,31}$ Since no spectral data of any kind has been reported for $\mathrm{Cu}$ (II) 
substituted AAP, structural modifications leading to the altered substrate specificity and hyperactivity are unknown.

In an effort to gain insight into the structure and function of dinuclear $\mathrm{Cu}(\mathrm{II})$ enzymes, we have recorded ${ }^{1} \mathrm{H}$ NMR spectra of $\mathrm{Cu}$ (II) substituted AAP ([CuCu(AAP)]) at $\mathrm{pH}$ 6.7. Analysis of the hyperfine shifted ${ }^{1} \mathrm{H}$ NMR signals along with $T_{1}$ values and nuclear Overhauser effect (NOE) difference spectra have facilitated the assignment of several of the hyperfine shifted ${ }^{1} \mathrm{H}$ NMR resonances. The temperature dependence of each hyperfine shifted signal was determined along with those of several model complexes. Fits of these data to the population distribution between the ground and first excited states provide information about the magnetic properties of dicopper(II) clusters. Our data demonstrate, for the first time, that ${ }^{1} \mathrm{H}$ NMR spectroscopy is a viable tool for structure-function studies on spincoupled dicopper(II) metalloprotein active sites.

\section{Materials and Methods}

Enzyme Purification. All chemicals used in this study were purchased commercially and were of the highest quality available. The aminopeptidase from Aeromonas proteolytica (AAP) was purified from a stock culture kindly provided by Professor Céline Schalk. Cultures were grown according to the previously published procedure, ${ }^{28}$ with minor modifications to the growth media. ${ }^{23}$ AAP was routinely purified and quantitated as described in detail elsewhere. ${ }^{21}$

Spectrophotometric Assay of AAP. AAP activity was measured by the method of Prescott and Wilkes ${ }^{28}$ as modified by Baker et al. ${ }^{33}$ In this assay, the hydrolysis of $0.5 \mathrm{mM}$ I-leucine- $p$-nitroanilide (10 mM Tricine, $\mathrm{pH} 8.0$ containing $0.1 \mathrm{mM} \mathrm{ZnSO}_{4}$ ) was measured spectrophotometrically at $25^{\circ} \mathrm{C}$ by monitoring the formation of $p$ nitroaniline at $405 \mathrm{~nm}\left(\Delta \varepsilon_{405}\right.$ value of $p$-nitroaniline of $10800 \mathrm{M}^{-1} \mathrm{~cm}^{-}$ $\left.{ }^{1}\right)$. The specific activity of purified AAP with I-leucine- $p$-nitroanilide was typically found to be 120 units per mg of enzyme. One unit was defined as the amount of enzyme that releases $1 \mu \mathrm{mol}$ of $p$-nitroaniline at $25^{\circ} \mathrm{C}$ in $60 \mathrm{~s}$. The specific activity determined for the dizinc(II) enzyme in this study was identical to that reported by Prescott and Wilkes. ${ }^{28}$ Enzyme concentrations were determined from the 
absorbance at $280 \mathrm{~nm}$ with the value $\varepsilon_{280}=41800 \mathrm{M}^{-1} \mathrm{~cm}^{-1} .^{34}$ The accuracy of this value was checked by the Edelhoch method ${ }^{35-37}$ using a 5:13:2 molar ratio mixture of $N$-acetyl-I-tryptophanamide, Gly-Tyramide, and I-cysteine, respectively, to model AAP. The molar absorptivity determined from this method $\left(\varepsilon_{280}=43950 \mathrm{M}^{-1} \mathrm{~cm}^{-1}\right)$ for AAP solubilized in $6 \mathrm{M}$ guanidine hydrochloride was in excellent agreement with the previously reported value by Prescott et al. ${ }^{34}$

Preparation of Cu(II)-Substituted AAP. Adventitious metal ions were removed from buffers by Chelex-100 resin (Sigma Chemical Company). All dilutions of enzyme and substrates were made with metal-free buffers in metal-free sterile plasticware. Dialysis tubing was prepared by boiling in deionized water and decanting the wash water. At least four such treatments were performed before the dialysis tubing was used. Apo-AAP was prepared by a method similar to that of Prescott et al. ${ }^{28,30}$ Briefly, AAP was dialyzed for $48 \mathrm{~h}$ at $4{ }^{\circ} \mathrm{C}$ against at least four changes of $10 \mathrm{mM} \mathrm{1,10-phenanthroline} \mathrm{in} 50 \mathrm{mM}$ Hepes buffer, $\mathrm{pH}$ 7.5. The 1,10-phenanthroline was removed by dialysis against $50 \mathrm{mM}$ Hepes buffer, $\mathrm{pH}$ 7.5, until it was undetectable in the solution outside the dialysis bag by absorbance readings at $327 \mathrm{~nm}$. The specific activity of apo-AAP was typically less than $5 \%$ of that of native AAP. Two and one-half equiv of $\mathrm{CuCl}_{2}$ (Strem Chemicals, Newburyport, $\mathrm{MA}, 99.999 \% \mathrm{CuCl}_{2}$ ) were added to apo-AAP resulting in an immediate color change to light green/yellow. Excess $\mathrm{Cu}$ (II) was removed by successive dilution and concentration of [CuCu(AAP)] in an Amicon Centricon-10 microconcentrator at pH 6.7. The electronic absorption spectrum of [CuCu(AAP)] at pH 6.7 in $50 \mathrm{mM}$ Hepes buffer shows a maximum at $730 \mathrm{~nm}$ with a molar absorptivity of $140 \mathrm{M}^{-1} \mathrm{~cm}^{-}$ 1 . These data are typical of tetragonally distorted $\mathrm{Cu}$ (II) centers found in Type 2 copper proteins. ${ }^{38} \mathrm{Cu}(\mathrm{II})$ substituted forms of AAP were assayed for activity with I-leucine- $p$-nitroanilide and I-alanine- $p$ nitroanilide and were entirely in agreement with those reported earlier. ${ }^{30,31}$ For example, the activities of $\mathrm{Cu}$ (II)-substituted AAP with Ileucine $p$-nitroanilide and I-alanine $p$-nitroanilide were 6.1 and 1.7 units per mg, respectively, compared to dizinc(II) AAP which had specific activities of 120 and 0.22 units per mg, respectively.

Physical Methods. All spectrophotometric measurements were performed on a Shimadzu UV-3101PC spectrophotometer equipped 
with a constant temperature holder and a Haake (Type 423) constant temperature circulating bath. Proton NMR spectra were recorded on a Bruker ARX-400 spectrometer at $400.13 \mathrm{MHz}$. A presaturation pulse or a modified-DEFT multipulse sequence was used to suppress the water signal and the resonances in the diamagnetic region. ${ }^{39}$ The pulse sequence repetition rate was typically $5 \mathrm{~s}^{-1}$ with a spectral window of $83 \mathrm{kHz}$. Chemical shifts (in ppm) were referenced to the residual water peak at $4.7 \mathrm{ppm}$. The ${ }^{1} \mathrm{H}$ NMR data were Fourier transformed with an exponential apodization function as well as the application of a $30 \mathrm{~Hz}$ line broadening. Longitudinal relaxation times $\left(T_{1}\right)$ were measured by the use of an inversion-recovery pulse sequence $\left(180^{\circ}-t-90^{\circ}\right)$. Plots of $\ln \left(I_{0}-I_{\mathrm{t}}\right)$ vs $t$ for each signal provided a straight line over all $t$ values investigated. Peak areas were determined as relative areas based on the 1:1 area ratio of signal $\mathrm{H}$. Nonbaseline subtracted spectra were used to determine these areas by the cut-and-weigh method. Nuclear Overhauser effect (NOE) difference spectra were obtained at $300 \mathrm{~K}$ by computer manipulation of the free induction decay with the saturation pulse set alternatively on the signal of interest and a reference position for $10 \mathrm{~ms}$. Steady-state NOE $\left(\eta_{i j}\right)$ on signal $i$ when signal $j$ is saturated for a period of time $t$ in paramagnetic metalloproteins is given by

$$
\eta_{1 \mathrm{y}}=\sigma_{\mathrm{i}} / \rho_{\mathrm{i}}=-0.1 \gamma^{4} h^{2} \eta_{\mathrm{H}}{ }^{-16} t_{\mathrm{e}} T_{\mathrm{I}}
$$

where $\sigma_{\mathrm{ij}}$ is the cross-relaxation between $i$ and $j, t_{\mathrm{c}}$ is the rotational correlation time of the molecule, $r_{\mathrm{i}}\left(T_{1}\right)$ is the spin-lattice relaxation rate of proton $i$, and $r_{\mathrm{ij}}$ is the distance between nuclei $i$, and $j$. The remaining constants have their usual meaning. All buffers for NMR samples contained 20\% 2-propanol to prevent aggregation at high protein concentrations. Purified enzyme stored for up to two weeks at $4{ }^{\circ} \mathrm{C}$ in $50 \mathrm{mM}$ Hepes buffer, $\mathrm{pH} 7.5$, containing $20 \%$ (by volume) 2 propanol, showed no measurable decrease in activity.

\section{Results and Discussion}

${ }^{1} \mathbf{H}$ NMR Spectra of [CuCu(AAP)] at pH 6.7. The $400 \mathrm{MHz}{ }^{1} \mathrm{H}$ NMR spectrum of [CuCu(AAP)] was recorded at $25^{\circ} \mathrm{C}$ in $\mathrm{H}_{2} \mathrm{O}$ buffered (Hepes) solution at pH 6.7 (Figure 1A). Several remarkably sharp, well resolved hyperfine shifted ${ }^{1} \mathrm{H}$ NMR signals were observed in the 70 to 
-20 ppm chemical shift range (Table 1 ). That hyperfine shifted signals are observed requires that the two $\mathrm{Cu}(\mathrm{II})$ ions be spin-coupled. Antiferromagnetically coupled dicopper(II) centers, for example, possess a singlet $(S=0)$ ground state and a triplet $(S=1)$ first excited state that differ in energy by the exchange constant, $2 J$. The proximity of the diamagnetic ground state and the first excited state provides a facile electronic relaxation mechanism. The ${ }^{1} \mathrm{H}$ NMR relaxation data (Table 1) suggests a room-temperature electron spin relaxation rate ( $\left.T_{1 \mathrm{e}}\right)$ of $\sim 10^{10}-10^{11} \mathrm{~s}^{-1}$. Systems with $T_{1 \mathrm{e}}$ 's on this order, such as lowspin $\mathrm{Fe}(\mathrm{III})$ or high-spin $\mathrm{Co}(\mathrm{II})$, generally provide relatively sharp hyperfine shifted ${ }^{1} \mathrm{H}$ NMR signals that can be assigned by modern NMR techniques. ${ }^{4,40,41}$ In addition, $\mathrm{Cu}(\mathrm{II})$ ions are less paramagnetic $(S=$ $1 / 2$ ) than high-spin Co(II) ions, for example, which results in only a small Curie relaxation contribution $\left(\propto T_{r} S^{2}(S+1)^{2}\right)$ so that hyperfine shifted signals will be relatively sharp even for large proteins ( $>80$ kDa.).

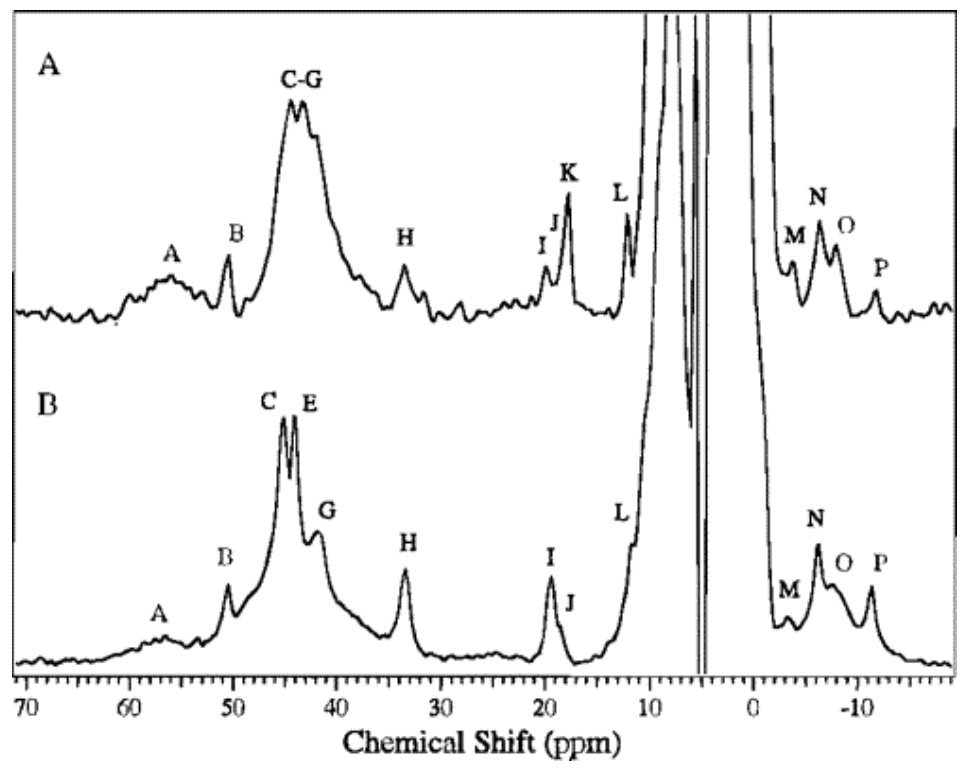

Figure $1^{1} \mathrm{H}$ NMR spectra of $(A)$ a $1 \mathrm{mM}$ sample of [CuCu(AAP)] in $\mathrm{H}_{2} \mathrm{O}$ (20 mM Hepes; $10 \%$ 2-propanol) at $300 \mathrm{~K}(\mathrm{pH} 6.7)$ and (B) a $1 \mathrm{mM}$ sample of [CuCu(AAP)] in $\mathrm{D}_{2} \mathrm{O}(20$ $\mathrm{mM}$ Hepes; $10 \%$ 2-propanol) at $300 \mathrm{~K}$ (pD 6.7). Both spectra were recorded using a presaturation pulse sequence to suppress the ${ }^{1} \mathrm{H}_{2} \mathrm{O}$ signal. Spectra were recorded at a repetition rate of $\sim 5 \mathrm{~s}^{-1}$ and a sufficiently wide bandwidth to cover all possible hyperfine shifted signals. 
NOT THE PUBLISHED VERSION; this is the author's final, peer-reviewed manuscript. The published version may be accessed by following the link in the citation at the bottom of the page.

Table 1. Properties of the Observed Hyperfine Shifted ${ }^{1} \mathrm{H}$ NMR Resonances of the Cu(II)-Substituted Aminopeptidase from Aeromonas proteolytica

\begin{tabular}{|c|c|c|c|c|c|c|}
\hline signal & assignment & $\begin{array}{l}\text { chemical shift }{ }^{a} \\
(\mathrm{ppm})\end{array}$ & $\begin{array}{l}\text { line width } \\
(\mathrm{Hz})\end{array}$ & $\begin{array}{l}\text { relative } \\
\text { areac }^{c}\end{array}$ & $\begin{array}{l}T_{1}^{d} \\
(\mathrm{~ms})\end{array}$ & temp dependence \\
\hline A & & $\sim 57$ & 2000 & $\sim 2$ & 3 & Curie \\
\hline B & $\mathrm{Asp}_{\mathrm{B}} \mathrm{C}^{b} \mathrm{H}$ & 50.4 & 240 & 1 & $>1$ & Curie \\
\hline \multirow[t]{2}{*}{ C } & $\mathrm{Asp}_{\mathrm{B}} \mathrm{C}^{b} \mathrm{H}$ & 45.2 & 410 & 2 & 2 & Curie \\
\hline & Glu $\mathrm{C}^{b} \mathrm{H}$ & & & & & \\
\hline $\mathrm{D}^{e}$ & $\mathrm{His} \mathrm{N}^{d} 2 \mathrm{H}$ & 44.6 & $\mathrm{ND}^{f}$ & $\mathrm{ND}^{f}$ & $\mathrm{ND}^{f}$ & $\mathrm{ND}^{f}$ \\
\hline$E$ & Glu $\mathrm{C}^{b} \mathrm{H}$ & 44.0 & 490 & 2 & 2 & Curie \\
\hline $\mathrm{F}^{e}$ & $\mathrm{His} \mathrm{N}^{d} 2 \mathrm{H}$ & 43.3 & $\mathrm{ND}^{f}$ & $\mathrm{ND}^{f}$ & $\mathrm{ND}^{f}$ & $\mathrm{ND}^{f}$ \\
\hline G & Glu $\mathrm{C}^{b} \mathrm{H}$ & 41.7 & 730 & 1 & 2 & Curie \\
\hline $\mathrm{H}$ & Glu $\mathrm{C}^{b} \mathrm{H}$ & 33.4 & 400 & 1 & 2 & Curie \\
\hline I & Glu $\mathrm{C}^{a} \mathrm{H}$ & 19.3 & 430 & 1 & 1 & Curie \\
\hline J & $\mathrm{His} \mathrm{C}^{b} \mathrm{H}$ & 18.5 & 210 & 1 & $\mathrm{ND}^{f}$ & Curie \\
\hline $\mathrm{K}^{e}$ & Peptide $\mathrm{N}-\mathrm{H}$ & 17.7 & 270 & 1 & $\mathrm{ND}^{f}$ & Curie \\
\hline L & $\mathrm{His} \mathrm{C}^{b} \mathrm{H}$ & 12.3 & 140 & 1 & 3 & $\mathrm{ND}^{f}$ \\
\hline M & & -3.2 & 490 & 1 & $>1$ & pseudo-Curie \\
\hline $\mathrm{N}$ & $\mathrm{Asp}_{\mathrm{B}} \mathrm{C}^{a} \mathrm{H}$ & -6.2 & 410 & 1 & 1 & pseudo-Curie \\
\hline $\mathrm{O}$ & & -7.7 & 730 & 1 & 3 & pseudo-Curie \\
\hline$P$ & & -11.4 & 410 & 1 & $>1$ & pseudo-Curie \\
\hline
\end{tabular}

${ }^{a}$ All chemical shifts are in ppm relative to the residual solvent signal at $4.7 \mathrm{ppm}$ for $\mathrm{H}_{2} \mathrm{O} .{ }^{b}$ Full width at half-maximum. ${ }^{c}$ Relative areas are based on the area of signal $\mathrm{H}^{d}{ }^{d} T_{1}$ values were obtained at $400 \mathrm{MHz}$ and $25^{\circ} \mathrm{C} .{ }^{e}$ Solvent-exchangeable. ${ }^{f}$ Not determined.

Among the observed resonances, signals $\mathrm{D}(44.6 \mathrm{ppm}), \mathrm{F}(43.3$ $\mathrm{ppm})$, and $\mathrm{K}(17.7 \mathrm{ppm})$ are solvent exchangeable (Figure $1 \mathrm{~B})$.

Examination of the $X$-ray crystal structure of AAP reveals that two histidine residues furnish ligands to the dimetal active site. ${ }^{16}$ The two most strongly downfield shifted signals ( $D$ and $F$ ) were assigned to imidazole $\mathrm{N}-\mathrm{H}$ protons of the two coordinated histidine residues. The observed chemical shifts for signals $\mathrm{D}$ and $\mathrm{F}$ are close to those of exchangeable benzimidazole $\mathrm{N}-\mathrm{H}$ protons observed for two ferromagnetically coupled dicopper(II) model complexes. ${ }^{16}$ The remaining exchangeable signal $(\mathrm{K})$ was assigned to a peptidyl $\mathrm{N}-\mathrm{H}$ proton that is in close proximity to the dicopper(II) center. Inspection of the X-ray crystal structure reveals that the $\mathrm{N}-\mathrm{H}$ peptidyl proton of Met180 resides $\sim 5.2 \AA$ from the dinuclear cluster; however, no fewer than six $\mathrm{N}-\mathrm{H}$ peptidyl protons are found within $10 \AA$ of the dinuclear cluster.

The observation of hyperfine shifted ${ }^{1} \mathrm{H}$ NMR signals for $[\mathrm{CuCu}(\mathrm{AAP})]$ was found to be dependent on $\mathrm{pH}$. As the $\mathrm{pH}$ was

Journal of the American Chemical Society, Vol 120, No. 25 (July 1, 1998): pg. 6329-6335. DOI. This article is (c) American Chemical Society and permission has been granted for this version to appear in e-Publications@Marquette. American Chemical Society does not grant permission for this article to be further copied/distributed or hosted elsewhere without the express permission from American Chemical Society. 
increased from 6.7 to 8.5 , the intensity of the observed NMR signals decreased and were no longer observed at $\mathrm{pH}$ values above 8.0. Upon returning the $\mathrm{pH}$ to 6.7 , the original ${ }^{1} \mathrm{H}$ NMR spectrum could be completely recovered. Moreover, the enzymatic activity of this sample, assayed at $\mathrm{pH} 8.0$, remained constant, and the metal content (as $\mathrm{Cu}$ ) was estimated to be $1.9 \pm 0.1$ by inductively coupled plasma atomic emission spectrometry (ICP-AES). Thus enzyme degradation or metal loss does not occur. Since the observation of hyperfine shifted ${ }^{1} \mathrm{H}$ NMR signals for dicopper(II) centers are a function of spin-coupling between the two $\mathrm{Cu}$ (II) ions, these data suggest that the two $\mathrm{Cu}$ (II) ions in [CuCu(AAP)] become uncoupled at high $\mathrm{pH}$ values. Therefore, the observed ${ }^{1} \mathrm{H}$ NMR signals result from a ( $\mu$-aqua) $(\mu-$ carboxylato)dicopper(II) core which is consistent with recent kinetic, EPR, and X-ray crystallographic studies that indicate at $\mathrm{pH}$ values less than 7.0 , the dimetal cluster contains a $\mu$-aquo bridge. ${ }^{21-23}$

\section{NOE Difference Spectra of [CuCu(AAP)] at pH 6.7.}

Assignment of several of the remaining hyperfine shifted signals was achieved by nuclear Overhauser effect (NOE) difference experiments. For paramagnetic metalloproteins with favorably short electron-spin relaxation times, steady-state NOE has been shown to be a useful tool for identifying pairs of nuclei in close proximity to one another..$^{40-42}$ Steady-state NOE methods were used to assign the observed hyperfine shifted signals of [CuCu(AAP)] instead of two-dimensional methods since all of the observed resonances have $T_{1}$ values less than $3 \mathrm{~ms}$, rendering signal assignment by 2D methods impossible at this time. Irradiation of signal A for $10 \mathrm{~ms}$ showed no detectable NOE cross-relaxation to any other observed signal. On the other hand, irradiation of signal B for 10 ms showed clear cross-relaxation to signals $\mathrm{C}$ and $\mathrm{N}$ indicating that these three protons are in close proximity to one another (Figure 2). To verify that irradiation of $B$ for $10 \mathrm{~ms}$ did not in turn partially irradiate signal $A$ or $C$, which are 6 and 5 ppm away from signal $B$, respectively, the decoupler was calibrated by irradiating a single resonance of ferricytochrome $\mathrm{C}$ that was less than 2 ppm away from a second resonance. ${ }^{43}$ In this experiment, irradiation of either signal showed no irradiation of the second. These data indicate that under our pulsing conditions, decoupler power spillover did not occur for hyperfine shifted ${ }^{1} \mathrm{H}$ NMR resonances separated by greater than or equal to $2 \mathrm{ppm}$. Therefore, protons $\mathrm{B}, \mathrm{C}$, and $\mathrm{N}$ can 
be assigned to a $\mathrm{Y}-\mathrm{CH}_{2}-\mathrm{CH}<$ amino acid side chain with $\mathrm{Y}$ ligated to the metal center. Of the possible amino acid residues that could produce such a pattern, only coordinated aspartate or histidine residues will give rise to the observed hyperfine shifts. However, the $T_{1}$ $\left(\propto r^{6} \mathrm{Cu}-\mathrm{H}\right)$ values are inappropriate for $\mathrm{N}_{\varepsilon}$-coordinated $\mathrm{His} \mathrm{C}^{\beta} \mathrm{H}$ protons since these protons will likely exhibit longer $T_{1}$ values and smaller hyperfine shifts, based on dicopper(II) model studies. ${ }^{40}$ Therefore, signals $\mathrm{B}, \mathrm{C}$, and $\mathrm{N}$ are assigned to an aspartate residue coordinated to the dicopper(II) cluster of AAP. Inspection of the X-ray crystal structure of AAP indicates that two aspartate residues furnish carboxylate ligands to the dimetal active site. Therefore, signals B, C, and $\mathrm{N}$ can result from either the bridging or terminal aspartic acid moiety.

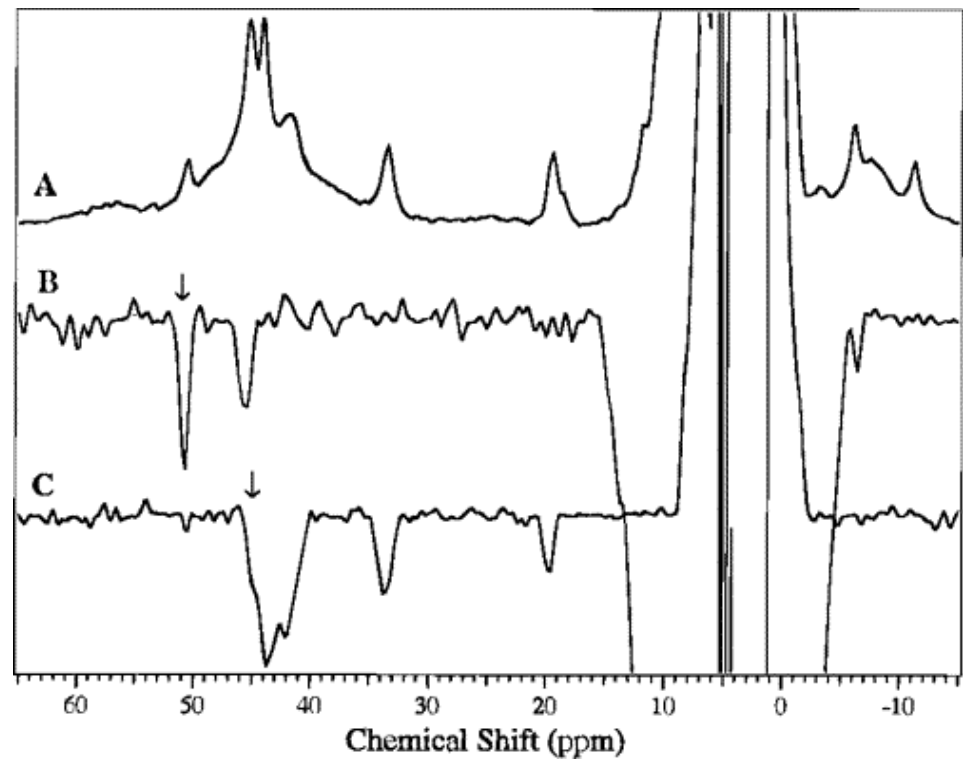

Figure 2 NOE difference ${ }^{1} \mathrm{H}$ NMR spectra of a $1 \mathrm{mM}$ sample of [CuCu(AAP)] in $\mathrm{D}_{2} \mathrm{O}$ (20 $\mathrm{mM}$ Hepes; $10 \%$ 2-propanol) at $300 \mathrm{~K}$ (pD 6.7) with the on resonance decoupler pulse set at the frequency indicated by the arrow. (A) ${ }^{1} \mathrm{H}$ NMR spectrum of a $1 \mathrm{mM}$ sample of $[\mathrm{CuCu}(\mathrm{AAP})]$ in $\mathrm{D}_{2} \mathrm{O}$. NOE difference spectrum with the decoupler pulse centered at (A) 51 and (B) $45 \mathrm{ppm}$.

NOE difference spectra were also recorded for signals $C-E, H$, and I-J at $25^{\circ} \mathrm{C}$. Saturation of signals $\mathrm{C}$ and $\mathrm{E}$ simultaneously for 10 ms revealed clear NOE cross-relaxation to signals G, H, and I (Figure 3). Likewise, irradiation of $\mathrm{H}$ showed clear NOE cross relaxation to signals C, E, and I. Moreover, simultaneous saturation of signals I and J for 10 ms showed clear NOE cross-relaxation to signals $C, E, G$, and L. These data indicate that signals $C, E, G, H$, and I are in close 
proximity to one another assigning them to the $\mathrm{Y}-\mathrm{CH}_{2}-\mathrm{CH}_{2}-\mathrm{CH}<$ protons of Glu152. The observation of cross-relaxation to signal $L$ upon irradiation of $\mathrm{I}-\mathrm{J}$ indicates that signals $\mathrm{J}$ and $\mathrm{L}$ likely make up a $\mathrm{C}^{\beta} \mathrm{H}$ pair. We propose that this $\mathrm{C}^{\beta} \mathrm{H}$ pair is due to one of the coordinated histidine residues since the two signals have smaller chemical shifts, as expected for $\mathrm{His} \mathrm{C}^{\beta} \mathrm{H}$ protons. The corresponding $\mathrm{C}^{\mathrm{a}} \mathrm{H}$ proton of the histidine ligand was not observed and is likely within the diamagnetic envelope. ${ }^{40}$

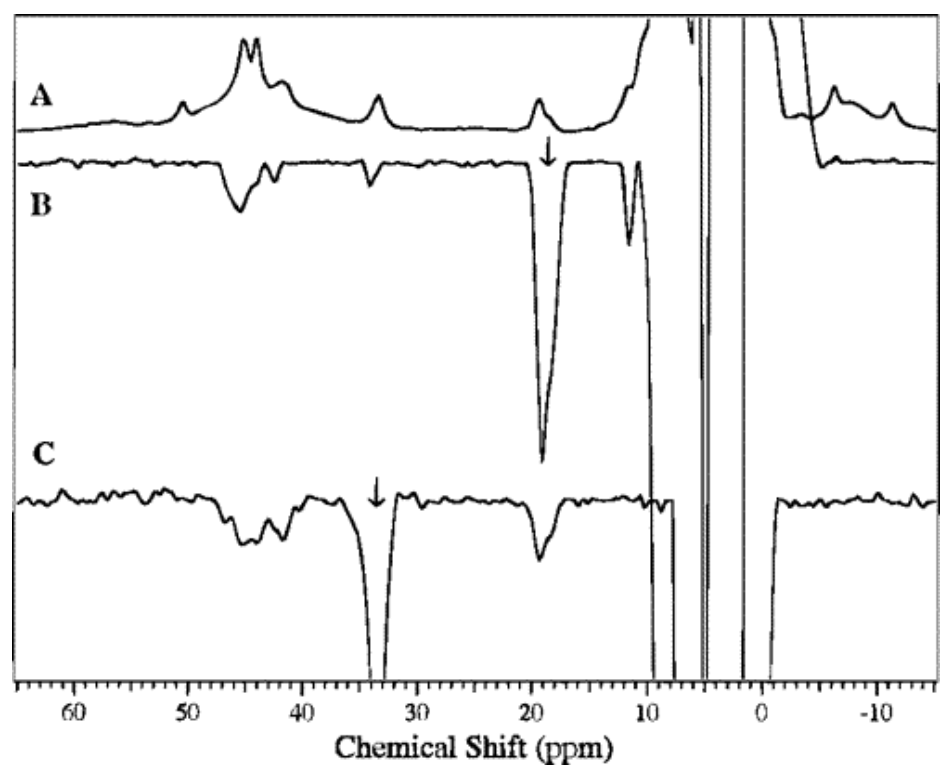

Figure 3 NOE difference ${ }^{1} \mathrm{H}$ NMR spectra of a $1 \mathrm{mM}$ sample of [CuCu(AAP)] in $\mathrm{D}_{2} \mathrm{O}(20$ $\mathrm{mM}$ Hepes; $10 \%$ 2-propanol) at $300 \mathrm{~K}$ (pD 6.7) with the on resonance decoupler pulse set at the frequency indicated by the arrow. (A) ${ }^{1} \mathrm{H}$ NMR spectrum of a $1 \mathrm{mM}$ sample of $[\mathrm{CuCu}(\mathrm{AAP})]$ in $\mathrm{D}_{2} \mathrm{O}$. NOE difference spectrum with the decoupler pulse centered at (A) 19 and (B) 33 ppm.

Temperature Studies. The temperature dependence of the observed hyperfine shifted ${ }^{1} \mathrm{H}$ NMR signals of [CuCu(AAP)] over the temperature range $276-308 \mathrm{~K}$ are shown as a Curie plot in Figure 4. Both Curie and anti-Curie temperature dependencies were observed for sets of hyperfine shifted protons. Signals $A-L$ followed Curie-like behavior (contact shift decreases with increasing temperature), while signals $\mathrm{M}-\mathrm{P}$ exhibited anti-Curie behavior (contact shift increases with increasing temperature). Inspection of Figure 4 reveals that the temperature dependence of the hyperfine shifted signals for [CuCu(AAP)] do not strictly follow Curie behavior. Linear regression analysis of the temperature dependence of the hyperfine shifted ${ }^{1} \mathrm{H}$ NMR signals of $[\mathrm{CuCu}(\mathrm{AAP})]$ revealed that signals $\mathrm{A}-\mathrm{H}$ extrapolate to 
NOT THE PUBLISHED VERSION; this is the author's final, peer-reviewed manuscript. The published version may be accessed by following the link in the citation at the bottom of the page.

chemical shift values upfield from 0 ppm, I and J show little dependence on temperature, while $\mathrm{M}-\mathrm{P}$ extrapolate to chemical shift values downfield from 0 ppm.

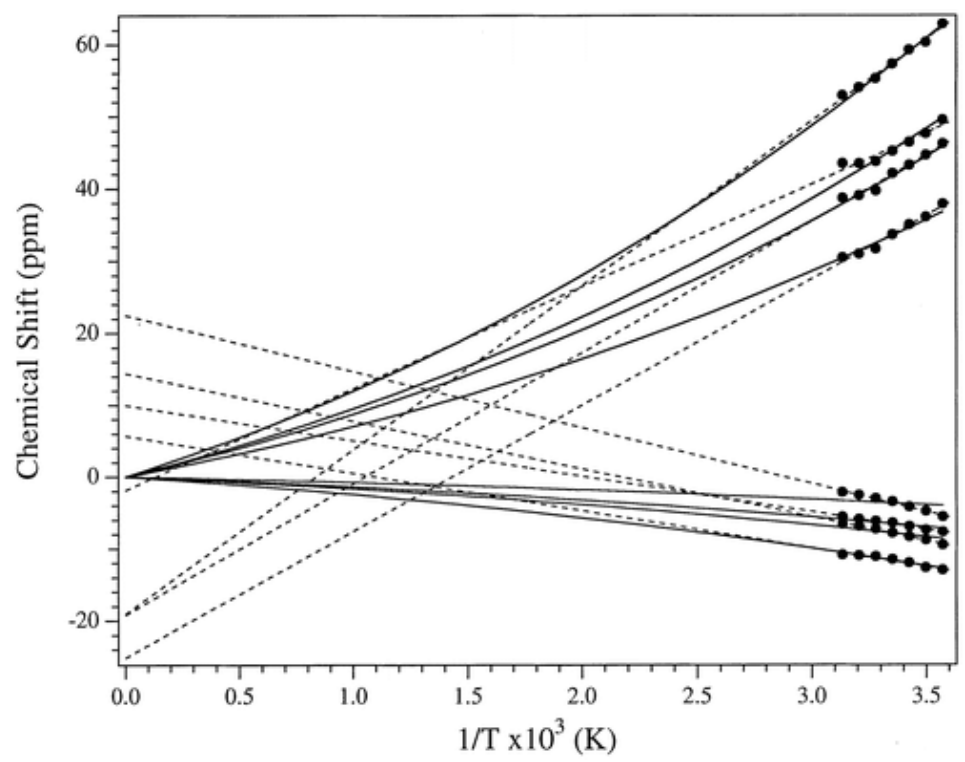

Figure 4 Temperature dependence of the hyperfine shifted ${ }^{1} \mathrm{H}$ NMR resonances of a 1 $\mathrm{mM}$ sample of [CuCu(AAP)] in $\mathrm{D}_{2} \mathrm{O}$ between 276 and $308 \mathrm{~K}$. The four downfield shifted signals ( 60 to $30 \mathrm{ppm}$ ) are $A, C, E$, and $H$, respectively, while the four upfield shifted signals ( -2 to $-12 \mathrm{ppm}$ ) are $\mathrm{M}, \mathrm{N}, \mathrm{O}$, and $\mathrm{P}$, respectively. The dashed lines are linear least-squares fit to the data while the solid lines are fits to eq 4.

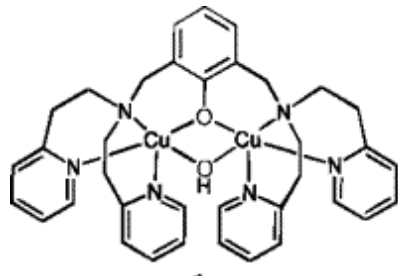

1<smiles>C1CCC1</smiles>

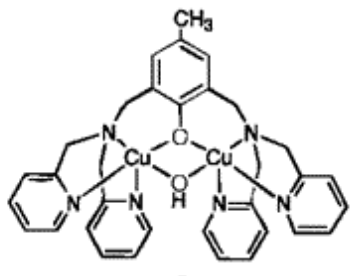

2

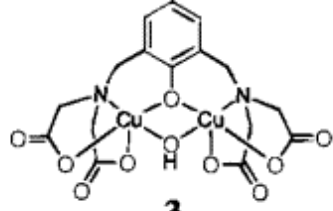

3
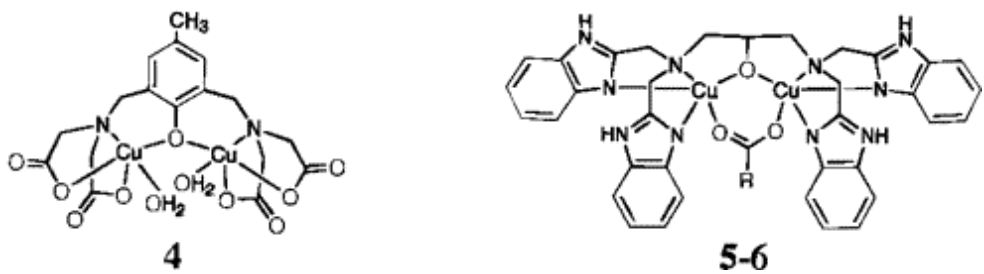

5-6

Figure 5 Schematic representations of $\left[\mathrm{Cu}_{2}(m-\mathrm{XYL})(\mathrm{OH})\right]^{2+}(\mathbf{1}),\left[\mathrm{Cu}_{2}(\mathrm{BPMP})(\mathrm{OH})\right]^{2+}$ (2), $\left[\mathrm{Cu}_{2}\left(\mathrm{CH}_{3} \mathrm{HXTA}\right)(\mathrm{OH})\right]^{2-}(\mathbf{3}),\left[\mathrm{Cu}_{2}\left(\mathrm{CH}_{3} \mathrm{HXTA}\right)\left(\mathrm{H}_{2} \mathrm{O}\right)_{2}\right]^{1-}(\mathbf{4}),\left[\mathrm{Cu}_{2}(\mathrm{TBHP})(\mathrm{OAC})\right]^{2+}(\mathbf{5})$, and $\left[\mathrm{Cu}_{2} \mathrm{TBHP}(\mathrm{OBz})\right]^{2+}(\mathbf{6})$. 
Deviations of hyperfine shift from Curie law can be understood by considering the presence of two closely spaced energy levels where the difference between the ground and excited states are on the order of $k T$. Since the two $\mathrm{Cu}(\mathrm{II})$ ions in AAP are spin-coupled, a term is added to the spin Hamiltonian of the form $-2 J S_{1} \cdot S_{2}$ where $S_{1}$ and $S_{2}$ are the spin vectors of the high spin $\mathrm{Cu}(\mathrm{II})$ ions, respectively, and $2 \mathrm{~J}$ is the exchange coupling constant. The states of a spin-coupled system of this type can be described by the total spin $S$ where $S=0$ and 1 . Therefore, the first excited-state energy is $2 J$ higher, relative to the ground state. At low temperatures $(k T \ll 2 J)$, only the ground $(S=0)$ state will be significantly populated; however, the first excited state will become populated as the temperature is raised $(k T \approx 2 \mathrm{~J})$.

In a very elegant study by Shokhirev and Walker, ${ }^{44}$ the temperature dependence of hyperfine shifted signals for multilevel systems were described. Their approach takes into account the thermal population of the excited state which allowed accurate simulation of the temperature dependence of the hyperfine shifted signals for several low-spin Fe(III) model hemes and heme proteins. ${ }^{45,46}$ By averaging the equations describing the hyperfine shift with their Boltzman weighting factors, the observed chemical shift $\left(\delta_{n}\right)$ is given by

$$
\delta_{u}=(1 / \mathrm{L}) \sum \delta_{n, \mathrm{~L}} W_{\mathrm{L}} \exp ^{-E_{\mathrm{I}} / 2 T}
$$

where $\delta_{n, L}$ is the hyperfine shift of nucleus $n$ in a pure electronic state $\mathrm{L}, Z$ is the statistical sum,

$$
Z=\sum W_{\mathrm{L}} \exp ^{-E_{0} \mu K T}
$$

and $W_{L}$ is the statistical weight of state $L\left(W_{L}=2 S_{L}+1\right)$. For a twolevel case, such as that found for dicopper(II) centers where only the $S=0$ and 1 levels are significantly populated at room temperature, eqs 2 and 3 can be combined and reduced to eq 4

$$
\delta_{n}=\frac{1}{T^{2}} \frac{W_{1} F_{\mathrm{n}, 1}+W_{2} F_{\mathrm{m}, 2} \exp ^{-\Delta E_{\mathrm{I}} / T}}{W_{1}+W_{2} \exp ^{-\Delta E_{1} / T}}
$$

Journal of the American Chemical Society, Vol 120, No. 25 (July 1, 1998): pg. 6329-6335. DOI. This article is (c) American Chemical Society and permission has been granted for this version to appear in e-Publications@Marquette. American Chemical Society does not grant permission for this article to be further copied/distributed or hosted elsewhere without the express permission from American Chemical Society. 
where $F_{\mathrm{n}, 1}$ and $F_{\mathrm{n}, 2}$ are the Curie factors of the ground and excited states, respectively, and $\Delta E_{\mathrm{L}}=\left(E_{2}-E_{1}\right)$. The temperature data obtained for eight of the observed hyperfine shifted signals for [CuCu(AAP)] were fit to eq 4 (Figure 4) using the program TDF21LVL kindly provided by Nikolai Shokhirev and Ann Walker. ${ }^{44}$ These fits provided a $\Delta E_{\mathrm{L}}$ value of $-50 \pm 40 \mathrm{~cm}^{-1}$ which gives a $2 \mathrm{~J}$ value of 50 $\mathrm{cm}^{-1}$. These data indicate that the two $\mathrm{Cu}(\mathrm{II})$ centers in AAP are weakly ferromagnetically coupled. This is consistent with the observation of an $S=3$ parallel mode EPR signal for [CoCo(AAP)], due to ferromagnetic coupling between the two $\mathrm{Co}$ (II) ions, at $\mathrm{pH}$ values below $8.0 .^{21}$

Hyperfine ${ }^{1} \mathrm{H}$ NMR chemical shifts were also recorded as a function of temperature for a series of magnetically diverse $\mu$-phenoxo and $\mu$-alkoxo dicopper(II) complexes (Figure 5). These complexes $\left[\mathrm{Cu}_{2}(m-\mathrm{XYL})(\mathrm{OH})\right]^{2+}(\mathbf{1}),\left[\mathrm{Cu}_{2}(\mathrm{BPMP})(\mathrm{OH})\right]^{2+}(\mathbf{2})$, $\left[\mathrm{Cu}_{2}\left(\mathrm{CH}_{3} \mathrm{HXTA}\right)(\mathrm{OH})\right]^{2-}(\mathbf{3}),\left[\mathrm{Cu}_{2}\left(\mathrm{CH}_{3} \mathrm{HXTA}\right)\left(\mathrm{H}_{2} \mathrm{O}\right)_{2}\right]^{-}(4)$, $\left[\mathrm{Cu}_{2}(\mathrm{TBHP})(\mathrm{OAC})\right]^{2+}(\mathbf{5})$, and $\left[\mathrm{Cu}_{2}(\mathrm{TBHP})(\mathrm{OBz})\right]^{2+}(\mathbf{6})$ have been extensively characterized by X-ray crystallography as well as several spectroscopic methods. ${ }^{12,47-50}$ The complete assignment of the ${ }^{1} \mathrm{H}$ NMR spectra of $\mathbf{1 - 6}$ have been previously reported. ${ }^{12,13,16}$ SQUID susceptibility studies indicate that $\mathbf{1}$ and $\mathbf{2}$ contain antiferromagnetically coupled $\mathrm{Cu}$ (II) ions with $2 \mathrm{~J}$ values of -600 and $-187 \mathrm{~cm}^{-1}$, respectively, 4 is a simple Curie-Weiss paramagnet and hence the $\mathrm{Cu}$ (II) ions are not coupled (2J $=0 \mathrm{~cm}^{-1}$ ), and 5 and $\mathbf{6}$ are ferromagnetically coupled with a $2 \mathrm{~J}$ value of $24 \mathrm{~cm}^{-1}$ for $\mathbf{5} \cdot{ }^{12,13,49,51}$ The magnetic properties of $\mathbf{1 - 6}$ in solution were confirmed by the Evans susceptibility method. ${ }^{52,53}$ At $25^{\circ} \mathrm{C}, \mu_{\text {eff }} / \mathrm{Cu}$ for $\mathbf{1 - 6}$ are $0.67,1.27$, $1.41,1.69,1.79$, and $1.82 \mu_{\mathrm{B}}$, respectively, consistent with the SQUID susceptibility data for $\mathbf{1 - 6}$ (Table 2 ).

Table 2. Summary of the Magnetic Interactions of Dicopper(II) Centers

$\begin{array}{llll}\text { complex } & 2 J(\mathrm{SQUID})\left(\mathrm{cm}^{-1}\right) & 2 J(\mathrm{TDF} 21 \mathrm{LVL}) & \mu_{\text {eff }} / \mathrm{Cu}^{a}(\mathrm{BM}) \\ {[\mathrm{CuCu}(m-\mathrm{XYL})(\mathrm{OH})]^{2+}} & -600 & -660 \mathrm{~cm}^{-1} \pm 80 & 0.67(0.33) \\ {[\mathrm{CuCu}(\mathrm{BPMP})(\mathrm{OH})]^{2+}} & -187 & -160 \mathrm{~cm}^{-1} \pm 40 & 1.27(0.62) \\ {\left[\mathrm{CuCu}\left(\mathrm{CH}_{3} \mathrm{HXTA}\right)(\mathrm{OH})\right]^{2-}} & & -120 \mathrm{~cm}^{-1} \pm 40 & 1.41(0.73) \\ {\left[\mathrm{CuCu}\left(\mathrm{CH}_{3} \mathrm{HXTA}\right)\left(\mathrm{H}_{2} \mathrm{O}\right)\right]^{-}} & 0 & 20 \mathrm{~cm}^{-1} \pm 20 & 1.69(0.97) \\ {[\mathrm{CuCu}(\mathrm{TBHP})(\mathrm{OAc})]^{2+}} & 24 & 70 \mathrm{~cm}^{-1} \pm 50 & 1.79(1.05) \\ {[\mathrm{CuCu}(\mathrm{TBHP})(\mathrm{OBz})]^{2+}} & & 30 \mathrm{~cm}^{-1} \pm 40 & 1.82(1.06)\end{array}$


NOT THE PUBLISHED VERSION; this is the author's final, peer-reviewed manuscript. The published version may be accessed by following the link in the citation at the bottom of the page.

[CuCu(AAP)] $50 \mathrm{~cm}^{-1} \pm 40$

${ }^{a}$ The values in parentheses are the number of electrons per $\mathrm{Cu}$ (II) center as calculated from the $\mu_{\text {eff }}$ value.

The temperature dependence of the hyperfine shifted signals of $\mathbf{1}, \mathbf{2}, \mathbf{5}$, and $\mathbf{6}$ were recorded over the temperature range -40 to $75{ }^{\circ} \mathrm{C}$ in acetonitrile- $d_{3}$ solutions, while those of $\mathbf{3}$ and $\mathbf{4}$ were recorded over the temperature range $0-90^{\circ} \mathrm{C}$ in $\mathrm{D}_{2} \mathrm{O}$ solutions. All of the hyperfine shifted signals for $\mathbf{2}$ (Figure 6), $\mathbf{3}$ (Figure S1, Supporting Information), 4 (Figure S2, Supporting Information), 5 (Figure 7A), and $\mathbf{6}$ (Figure 7B) sharpen and shift toward the diamagnetic region as the temperature is increased following Curie behavior. Conversely, all the observed resonances for $\mathbf{1}$ (Figure 8) broaden and shift away from the diamagnetic region as the temperature is increased following antiCurie behavior. Analysis of a $\mathrm{X}$ vs $T$ plot for antiferromagnetically coupled systems reveals a temperature maximum, $T_{\mathrm{N}}$ (Néel Temperature). $T_{\mathrm{N}}$ values were calculated using the Bleaney-Bowers expression for 1-3 and were found to be 540, 160, and $100 \mathrm{~K}$, respectively, based upon SQUID susceptibility data. ${ }^{54}$ These data suggest that within our accessible temperature range, $\mathbf{2}$ and $\mathbf{3}$ fall on the $X$ vs $T$ plot where $x$ is decreasing with increasing temperature, while 1 falls in the region where $X$ is increasing with increasing temperature. ${ }^{14}$ On the other hand, $X$ vs $T$ plots for ferromagnetically coupled systems are second-order where $X$ decreases with increasing temperature through a transition temperature, $T_{\mathrm{C}}$ (Curie temperature). The temperature dependence observed for the hyperfine shifted ${ }^{1} \mathrm{H}$ NMR signals of antiferromagnetically coupled model complexes have been previously correlated to their magnetic properties by the Evans susceptibility method. ${ }^{14}$ As expected, the slopes of the $X$ vs T plots for 2-4 are negative while that of $\mathbf{1}$ is positive. These data follow exactly the $X$ vs $T$ plots generated from SQUID susceptibility data and confirm that the observed temperature dependence of the hyperfine shifted ${ }^{1} \mathrm{H}$ NMR signals are a direct result of the magnitude of the coupling constant.

Journal of the American Chemical Society, Vol 120, No. 25 (July 1, 1998): pg. 6329-6335. DOI. This article is (C) American Chemical Society and permission has been granted for this version to appear in e-Publications@Marquette. American Chemical Society does not grant permission for this article to be further copied/distributed or hosted elsewhere without the express permission from American Chemical Society. 
NOT THE PUBLISHED VERSION; this is the author's final, peer-reviewed manuscript. The published version may be accessed by following the link in the citation at the bottom of the page.

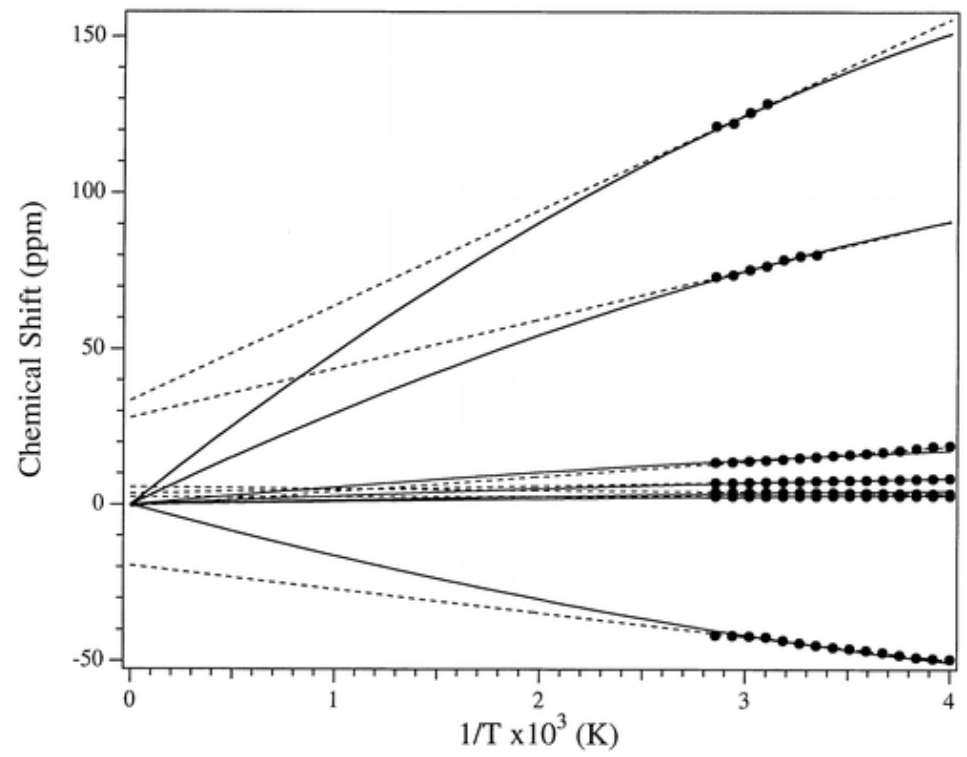

Figure 6 Curie plot of the hyperfine shifted ${ }^{1} \mathrm{H}$ NMR resonances of a $15 \mathrm{mM}$ sample of $\left[\mathrm{Cu}_{2} \mathrm{BPMP}(\mathrm{OH})\right]^{2+}(2)$ in acetonitrile- $d_{3}$ solution between 233 and $348 \mathrm{~K}$. The dashed lines are linear least-squares fit to the data, while the solid lines are fits to eq 4.
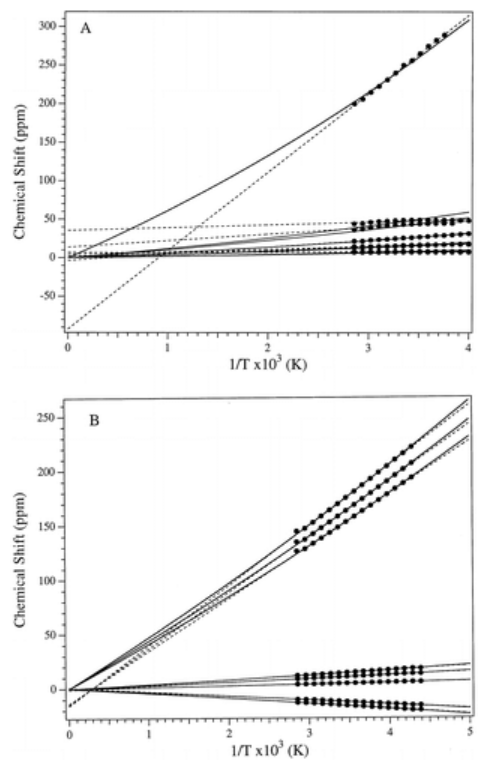

Figure 7 Curie plots of the hyperfine shifted ${ }^{1} \mathrm{H}$ NMR resonances of $15 \mathrm{mM}$ samples of (A) $\left[\mathrm{Cu}_{2} \mathrm{TBHP}(\mathrm{OAC})\right]^{2+}(\mathbf{5})$ and $(\mathrm{B})\left[\mathrm{Cu}_{2} \mathrm{TBHP}(\mathrm{OBz})\right]^{2+}(\mathbf{6})$ in acetonitrile- $d_{3}$ solution between 233 and $348 \mathrm{~K}$. The dashed lines are linear least-squares fit to the data, while the solid lines are fits to eq 4.

Journal of the American Chemical Society, Vol 120, No. 25 (July 1, 1998): pg. 6329-6335. DOI. This article is (c) American Chemical Society and permission has been granted for this version to appear in e-Publications@Marquette. American Chemical Society does not grant permission for this article to be further copied/distributed or hosted elsewhere without the express permission from American Chemical Society. 


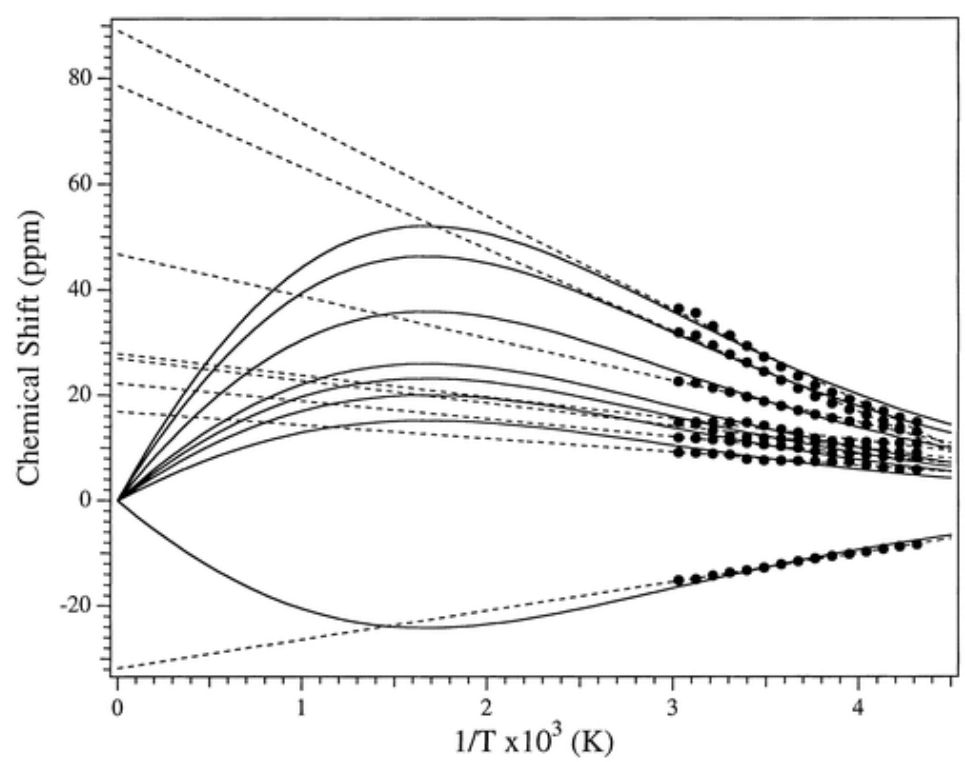

Figure 8 Curie plot of the hyperfine shifted ${ }^{1} \mathrm{H}$ NMR resonances of a $12 \mathrm{mM}$ sample of $\left[\mathrm{Cu}_{2} m-\mathrm{XYL}(\mathrm{OH})\right]^{2+}(\mathbf{1})$ in acetonitrile- $d_{3}$ solution between 233 and $348 \mathrm{~K}$. The dashed lines are linear least-squares fit to the data while the solid lines are fits to eq 4.

The temperature data obtained for up to eight of the observed hyperfine shifted ${ }^{1} \mathrm{H}$ NMR resonances for $\mathbf{1}-\mathbf{6}$ were fit to eq 4 using the program TDF21LVL (Table 2; Figures $6-8) .{ }^{44}$ Since only eight signals could be fit simultaneously, resonances were selected from across the entire observed chemical shift range. Resonances due to $\mathrm{C}^{\beta} \mathrm{H}$ protons of carboxylate arms were excluded from the fits of $\mathbf{3}$ and 4 due to temperature-dependent chemical exchange mechanisms. The calculated $2 J$ values for 1-6 are consistent with Evans susceptibility studies as well as $2 \mathrm{~J}$ values determined from SQUID susceptibility studies (Table 2). The large errors associated with the calculated values results from the relatively small temperature range over which these complexes could be studied. Inspection of Figures 6 and 7 reveals that the slope of the least-squares fit to the temperature data is indicative of the sign of $2 \mathrm{~J}$. For antiferromagnetically coupled dicopper(II) centers the least-squares fits of downfield hyperfine shifted signals extrapolate to chemical shift values downfield of their diamagnetic chemical shift values. On the other hand, least-squares fits of downfield hyperfine shifted signals for ferromagnetically coupled dicopper(II) centers extrapolate to chemical shift values upfield of their diamagnetic shift values. The same trend is true for upfield shifted signals. These data are consistent with the $X$ vs $T$ plots for both antiferromagnetically and ferromagnetically coupled dicopper(II) 
centers and are consistent with the two $\mathrm{Cu}(\mathrm{II})$ ions in AAP being weakly ferromagnetically coupled.

Mechanistic Implications. Combination of the available X-ray crystallographic, kinetic, and previously reported spectroscopic data allowed one of us to recently propose a mechanism of action for AAP. ${ }^{21,23}$ In the resting [CuCu(AAP)] enzyme at $\mathrm{pH} 6.7$, the observation of a ${ }^{1} \mathrm{H}$ NMR spectrum clearly demonstrates that the two metal ions in the dinuclear active site magnetically interact with one another and, therefore, are capable of modulating each others catalytic properties. This point is emphasized by the fact that the addition of $1 \mathrm{~mol}$ of $\mathrm{Cu}$ (II) or $\mathrm{Ni}$ (II) to apo-AAP followed by the addition of $\mathrm{Zn}$ (II) enhances the enzymatic activity nearly 100 -fold. ${ }^{30}$ Thus, the dinuclearity of the active site is intimately involved in catalysis. We propose that the observed ${ }^{1} \mathrm{H}$ NMR signals for [CuCu(AAP)] and the weak ferromagnetic coupling between the two $\mathrm{Cu}(\mathrm{II})$ ions results from a ( $\mu$-aqua)( $\mu$-carboxylato)dicopper(II) core. This is consistent with recent kinetic, EPR, and X-ray crystallographic studies that indicate at $\mathrm{pH}$ values less than 7.5 the dimetal cluster contains a $\mu$-aquo bridge. ${ }^{21-23}$ These data are also consistent with the observation of an $S=3$ parallel mode EPR signal for [CoCo(AAP)], due to ferromagnetic coupling between the two $\mathrm{Co}$ (II) ions, at $\mathrm{pH}$ values below 8.0.21 The loss of the bridging water molecule at $\mathrm{pH}$ values above 8.0 is suggested by the complete loss of the observed hyperfine shifted ${ }^{1} \mathrm{H}$ NMR spectrum of [CuCu(AAP)] at $\mathrm{pH}$ values above 8.0. These data are consistent with the $\mathrm{p} K_{\mathrm{a}}$ value of 7.0 determined for the coordinated water/hydroxide by enzyme kinetic methods. ${ }^{23}$ In addition, at $\mathrm{pH}$ values above 8.0, the observed $S=3$ parallel mode EPR signal for [CoCo(AAP)] is lost. Concomitant with the loss of the $S$ $=3$ signal, an increase in the $S=3 / 2$ signal due to uncoupled [CoCo(AAP)] was observed. Therefore, an ionizable group mediates spin-coupling between the two divalent metal centers in AAP and this ionizable group is likely the nucleophile in the catalytic reaction. ${ }^{22}$

AAP is ca. $80 \%$ active with only a single $\mathrm{Zn}(\mathrm{II})$ ion bound and recent fluoride inhibition studies indicated that fluoride binding occurred only after substrate binding. ${ }^{22}$ These data suggest that the bridging water molecule becomes terminal upon substrate binding and is bound to a single $\mathrm{Zn}$ (II) site. Based on the previously reported 
absorption and EPR data for [Co (AAP)], [CoCo(AAP)], [CoZn(AAP)], and $[\mathrm{ZnCo}(\mathrm{AAP})]$ in the presence and absence of butaneboronic acid (BuBA), a substrate analogue inhibitor, it was proposed that BuBA binds only to the first metal center but not to the second. 21,22 These data are consistent with the loss of the $S=3$ EPR signal of [CoCo(AAP)] upon BuBA binding. ${ }^{21}$ Based on X-ray crystallographic data of a transition-state analogue inhibitor-AAP complex, the carbonyl oxygen of the peptide indeed binds directly to the $\mathrm{Zn}$ (II) ion coordinated to His256 and Glu152. ${ }^{55}$ This binding scheme is consistent with the large negative entropy and large positive enthalpy of activation reported for AAP. ${ }^{23}$ Thus, the bridging water/hydroxide becomes terminal at high $\mathrm{pH}$ values as well as upon substrate binding and appears to represent the hydroxylating agent in the enzymatic reaction. We therefore propose that the first metal ion binds substrate and delivers the active site nucleophile, while the second metal ion assists in the stabilization of the transition state of the hydrolytic reaction.

In conclusion, we report herein the ${ }^{1} \mathrm{H}$ NMR spectrum of a spincoupled dinuclear $\mathrm{Cu}$ (II) active site in a metalloprotein. These studies have facilitated the assignment of several of the observed hyperfine shifted signals of active site ligands in [CuCu(AAP)]. Our data demonstrate, for the first time, that ${ }^{1} \mathrm{H}$ NMR spectra can be easily obtained for spin-coupled dinuclear copper(II) centers in metalloenzymes and that ${ }^{1} \mathrm{H}$ NMR spectroscopy is a viable tool for structure-function studies of dinuclear $\mathrm{Cu}$ (II) enzymes. These data also establish that $\mathrm{Cu}$ (II) substituted AAP contains two type-2 tetragonally distorted $\mathrm{Cu}(\mathrm{II})$ ions that are weakly ferromagnetically coupled with a $2 \mathrm{~J}$ value of $50 \pm 40 \mathrm{~cm}^{-1}$. This is the first structural information regarding the hyperactive [CuCu(AAP)] enzyme and indicates that a bridging water molecule mediates the spin-coupling between the two $\mathrm{Cu}(\mathrm{II})$ centers in AAP.

\section{Acknowledgment}

This work was supported by the National Science Foundation (CHE-9422098; R.C.H.). The Bruker ARX-400 NMR spectrometer was purchased with funds provided by the National Science Foundation (CHE-9311730; R.C.H.) and Utah State University. 
NOT THE PUBLISHED VERSION; this is the author's final, peer-reviewed manuscript. The published version may be accessed by following the link in the citation at the bottom of the page.

\section{Supporting Information Available}

Fits of the chemical shift vs $1 / T$ for the model complexes 3 (Figure S1) and 4 (Figure S2) given in Table 2 (3 pages, print/PDF). See any current masthead page for ordering information and Web access instructions.

\section{References}

${ }^{1}$ (a) Utah State University. (b) University of South Florida.

${ }^{2}$ Sorrell, T. N. Tetrahedron 1989, 45, 3-68.

${ }^{3}$ Karlin, K. D.; Tyeklar, Z. Bioinorganic Chemistry of Copper; Chapman \& Hill: New York, 1993.

${ }^{4}$ Bertini, I.; Luchinat, C. NMR of Paramagnetic Molecules in Biological Systems; Benjamin \& Cummings: Menlo Park, CA, 1986.

${ }^{5}$ Zelonka, R. A.; Baird, M. C. Inorg. Chem. 1972, 11, 134-137.

${ }^{6}$ Wang, S.; Pang, Z.; Zheng, J.-C.; Wagner, M. J. Inorg. Chem. 1993, 32, 5975-5980.

${ }^{7}$ Byers, W.; Williams, R. J. P. J. Chem. Soc., Dalton Trans. 1972, 555-560.

${ }^{8}$ Dei, A.; Gatteschi, D.; Piergentili, E. Inorg. Chem. 1979, 18, 89-93.

${ }^{9}$ Kitajima, N.; Fujisawa, K.; Fujimoto, C.; Moro-oka, Y.; Hashimoto, S.; Kitagawa, T.; Toriumi, K.; Tatsumi, K.; Nakamura, A. J. Am. Chem. Soc. 1992, 114, 1277-1291.

${ }^{10}$ Murthy, N. N.; Karlin, K. D.; Bertini, I.; Luchinat, C. J. Am. Chem. Soc. 1997, 119, 2156-2162.

${ }^{11}$ Maekawa, M.; Kitagawa, S.; Munakata, M.; Masuda, H. Inorg. Chem. 1989, 28, 1904-1909.

${ }^{12} \mathrm{Holz}$, R. C.; Brink, J. M.; Gobena, F. T.; O'Connor, C. J. Inorg. Chem. 1994, 33, 6086-6092.

${ }^{13} \mathrm{Holz}$, R. C.; Brink, J. M. Inorg. Chem. 1994, 33, 4609-4610.

${ }^{14} \mathrm{Holz}$, R. C.; Brink, J. M.; Rose, R. R. J. Magn. Reson. A 1996, 119, 125-128.

${ }^{15} \mathrm{Holz}$, R. C.; Gobena, F. T. Polyhedron 1996, 15, 2179-2185.

${ }^{16}$ Brink, J. M.; Rose, R. R.; Holz, R. C. Inorg. Chem. 1996, 35, 2878-2885.

${ }^{17}$ Satcher, J. H.; Balch, A. L. Inorg. Chem. 1995, 34, 3371-3373.

${ }^{18}$ Kalverda, A. P.; Salgado, J.; Dennison, C. ; Canters, G. W. Biochemistry 1996, 35, 3085-3092.

${ }^{19}$ Drago, R. S. Physical Methods for Chemists, 2nd ed.; Saunders: Orlando, $\mathrm{FL}, 1992$.

${ }^{20} \mathrm{Holz}$, R. C.; Bradshaw, J. M.; Bennett, B. Inorg. Chem. 1997, submitted.

${ }^{21}$ Bennett, B.; Holz, R. C. J. Am. Chem. Soc. 1997, 119, 1923-1933.

${ }^{22}$ Bennett, B.; Holz, R. C. Biochemistry 1997, 36, 9837-9846.

${ }^{23}$ Chen, G.; Edwards, T.; D'souza, V. M.; Holz, R. C. Biochemistry 1997, 36, 4278-4286.

Journal of the American Chemical Society, Vol 120, No. 25 (July 1, 1998): pg. 6329-6335. DOI. This article is (c) American Chemical Society and permission has been granted for this version to appear in e-Publications@Marquette. American Chemical Society does not grant permission for this article to be further copied/distributed or hosted elsewhere without the express permission from American Chemical Society. 
NOT THE PUBLISHED VERSION; this is the author's final, peer-reviewed manuscript. The published version may be accessed by following the link in the citation at the bottom of the page.

${ }^{24}$ Lin, L.-Y.; Park, H. I.; Ming, L.-J. JBIC 1997, 2, 744-749.

${ }^{25}$ Taylor, A. FASEB J. 1993, 7, 290-298.

${ }^{26}$ Taylor, A. TIBS 1993, 18, 167-172.

${ }^{27}$ Aminopeptidases; Taylor, A., Ed.; R. G. Landes Co.: Austin, TX, 1996; pp $1-219$.

${ }^{28}$ Prescott, J. M.; Wilkes, S. H. Methods Enzymol. 1976, 45B, 530-543.

${ }^{29}$ Chevrier, B.; Schalk, C.; D'Orchymont, H.; Rondeau, J.-M.; Moras, D.;

Tarnus, C. Structure 1994, 2, 283-291.

${ }^{30}$ Prescott, J. M.; Wagner, F. W.; Holmquist, B.; Vallee, B. L. Biochem.

Biophys. Res. Commun. 1983, 114, 646-652.

${ }^{31}$ Prescott, J. M.; Wagner, F. W.; Holmquist, B.; Vallee, B. L. Biochemistry

$1985,24,5350-5356$.

${ }^{32}$ Bayliss, M. E.; Prescott, J. M. Biochemistry 1986, 25, 8113-8117.

${ }^{33}$ Baker, J. O.; Wilkes, S. H.; Bayliss, M. E.; Prescott, J. M. Biochemistry 1983, 22, 2098-2103.

${ }^{34}$ Prescott, J. M.; Wilkes, S. H.; Wagner, F. W.; Wilson, K. J. J. Biol. Chem. 1971, 246, 1756-1764.

${ }^{35}$ Gill, S. C.; von Hippel, P. H. Anal. Biochem. 1989, 182, 319-326.

${ }^{36}$ Gill, S. C.; von Hippel, P. H. Anal. Biochem. 1990, 189, 283.

${ }^{37}$ Edelhoch, H. Biochemistry 1967, 6, 1948-1954.

${ }^{38}$ Solomon, E. I.; Lowery, M. D.; Lacroix, L. B.; Root, D. E. In Methods Enzymol. 1993; Vol. 226, pp 1-33.

${ }^{39}$ Kerby, R.; Zeikus, J. G. J. Bacteriol. 1987, 169, 5605-5609.

${ }^{40}$ Bertini, I.; Turano, P.; Vila, A. J. Chem. Rev. 1993, 93, 2833-2932.

${ }^{41}$ NMR Methodology for Paramagnetic Proteins; La Mar, G. N., de Ropp, J. S., Eds.; Plenum Press: New York, 1993; Vol. 12, pp 1-78.

${ }^{42}$ Cheng, H.; Markley, J. L. Annu. Rev. Biophys. Biomol. Struct. 1995, 24, 209-237.

${ }^{43}$ Lanzilotta, W. N.; Holz, R. C.; Seefledt, L. C. Biochemistry 1995, 34, $15646-15653$

${ }^{44}$ Shokhirev, N. V.; Walker, F. A. J. Phys. Chem. 1995, 99, 17795-17804.

${ }^{45}$ Horrocks, W. D.; Greenberg, E. S. Biochim. Biophys. Acta 1973, 322, $38-44$

${ }^{46}$ Horrocks, W. D.; Greenberg, E. S. Mol. Phys. 1974, 27, 993-999.

${ }^{47}$ Maloney, J. J.; Glogowski, M.; Rohrbach, D. F.; Urbach, F. L. Inorg. Chim. Acta 1987, 127, L33-L35.

${ }^{48}$ Karlin, K. D.; Hayes, J. C.; Gultneh, Y.; Cruse, R. W.; McKown, J. W.; Hutchinson, J. P.; Zubieta, J. J. Am. Chem. Soc. 1984, 106, 2121-2128.

${ }^{49}$ Karlin, K. D. ; Farooq, A. ; Hayes, J. C.; Brett, I. C. ; Rowe, T. M.; Sinn, E.; Zubieta, J. Inorg. Chem. 1987, 26, 1271-1280.

${ }^{50}$ Abbreviations: $\mathrm{CH}_{3} \mathrm{HXTA}=N, \mathrm{~N}^{\prime}$-(2-hydroxy-5-methyl-1,3-xylylene)bis $(N-$ carboxymethylglycine); BPMP = 2,6-bis[[bis(2-

Journal of the American Chemical Society, Vol 120, No. 25 (July 1, 1998): pg. 6329-6335. DOI. This article is (c) American Chemical Society and permission has been granted for this version to appear in e-Publications@Marquette. American Chemical Society does not grant permission for this article to be further copied/distributed or hosted elsewhere without the express permission from American Chemical Society. 
NOT THE PUBLISHED VERSION; this is the author's final, peer-reviewed manuscript. The published version may be accessed by following the link in the citation at the bottom of the page.

pyridylmethyl)amino]methyl]-4-methylphenol; $m-X Y L=2,6-$ bis[[bis(2-pyridylethyl)amino]methyl]phenol; TBHP $=N, N, N{ }^{\prime}, N$ tetrakis[(2-benzimidazolyl)methyl]-2-hydroxy-1,3-diaminopropane.

${ }^{51}$ McKee, V.; Zvagulis, M.; Dagdigian, J. V.; Patch, M. G.; Reed, C. A. J. Am. Chem. Soc. 1984, 106, 4765-4772.

${ }^{52}$ Evans, D. F. J. Chem. Soc. 1959, 2003-2005.

${ }^{53}$ Phillips, W. D.; Poe, M. Methods Enzymol. 1972, 24, 304-317.

${ }^{54}$ O'Connor, C. J. Prog. Inorg. Chem. 1982, 29, 203-283.

${ }^{55}$ Chevrier, B.; D'Orchymont, H.; Schalk, C.; Tarnus, C.; Moras, D. Eur. J. Biochem. 1996, 237, 393-398. 